\title{
PRESENTING DYKE-DAVIDOFF MASSON SYNDROME WITHOUT MENTAL RETARDATION
}

\author{
Ram Dayal Singh ${ }^{1}$, Kumar Abhinav²
}

${ }^{1}$ Associate Professor, Department of Internal Medicine, Patna Medical College and Hospital (PMCH), Patna.

2Junior Resident, Department of Internal Medicine, Patna Medical College and Hospital (PMCH), Patna.

\section{ABSTRACT}

\section{BACKGROUND}

'The Dyke-Davidoff Masson syndrome usually present with triad of hemiplegia seizure and mental retardation. In this case, the delivery of patient was uneventful and he developed dragging of left leg at the age of 15 months. He developed 1st episode of seizure at the age of 10 yrs., which was managed on multiple drugs. The patient came to PMCH for UTI, but during investigation (MRI brain) we diagnosed it as Dyke-Davidoff Masson syndrome. As patient is a teacher, his IQ was held to be normal. Hence, we are referring the case to your Journal presenting with hemiparesis and seizure without mental retardation, which is a rare presentation of this rare disease.

\section{KEYWORDS}

Dyke-Davidoff Masson Syndrome, Mental Retardation, Brain.

HOW TO CITE THIS ARTICLE: Singh RD, Abhinav K. Presenting Dyke-Davidoff Masson syndrome without mental retardation. J. Evolution Med. Dent. Sci. 2017;6(30):2484-2485, DOI: 10.14260/Jemds/2017/537

\section{BACKGROUND}

Dyke-Davidoff Masson syndrome is an atrophy or hypoplasia of one cerebral hemisphere from brain insult in foetal or early childhood period. It usually presents as clinical triad of Hemiplegia, Seizure and Mental retardation. First described by Dyke, Davidoff and Masson in 1933,(1) it is infrequently encountered disease entity in clinical practice. As our patient presented with left-sided hemiparesis and seizure without mental retardation, we find it befitting to report this case.

\section{CASE REPORT}

A 30 year male developed fever with burning sensation during micturition on 6th Feb. 16. Treatment was started by a local doctor with no relief. On 26th Feb. 16, he had generalised tonic-clonic convulsion twice during the day time and then he reported to medical emergency of Patna Medical College and Hospital on 27th Feb. 16. Patient's father revealed a long past history during detailed history taking and clinical examination.

He was delivered full term at Sadar Hospital, Hajipur (Bihar). The delivery was normal and his antenatal, perinatal and neonatal periods were uneventful according to his parents. At the age of 15 months, parents noticed that he used to drag his left leg during walking with a tendency to sway toward left side, but milestones of development were normal. He developed normally till the age of 10 yrs. when he noticed first episode of generalised tonic-clonic seizure, which was treated by local doctors. Despite the slight left-sided weakness, his performance at school was satisfactory and he passed 10th class well. His further study was discontinued due to economic reasons and he started teaching in a private school. As the frequency of seizure increased, he was treated

Financial or Other, Competing Interest: None.

Submission 28-02-2017, Peer Review 01-04-2017,

Acceptance 07-04-2017, Published 13-04-2017.

Corresponding Author:

Dr. Ram Dayal Singh

Quarter No. 5

Back Harding Road,

Patna-800001, Bihar

E-mail:dr_rdsingh@yahoo.in

DOI: $10.14260 /$ jemds $/ 2017 / 537$

\section{(c) $(1) \$$}

at RIMS Ranchi and IGIMS Patna and he was put on a combination of multiple anti-epileptic drugs (Carbamazepine $400 \mathrm{mg} \mathrm{x} 3$, Phenobarbitone $60 \mathrm{mg} \mathrm{x} 2$, Clobazam $10 \mathrm{mg} \mathrm{x} 2$, topiramate $200 \mathrm{mg} \mathrm{x}$ ). His seizure was controlled for last 10 yrs. on these drugs and he was continuing his teaching job well. He is unmarried, having two brothers and one sister and they are healthy and doing well.

On 27 Feb. 16, his pulse was 88/min, B.P -120/70, Temp $104^{\circ} \mathrm{F}$, Cyanosis, pedal oedema, clubbing, icterus and lymphadenopathy were absent. Teeth, gums and thyroid were normal. Examination of respiratory system, cardiovascular system and abdomen were normal.

On 27 Feb. 16, patient was fully conscious and higher mental function including speech and memory were normal. All cranial nerves were normal. On neurological examination, left side of body was revealing. Power was slightly decreased (Grade 4/5) in both upper and lower limbs, deep tendon jerks were slightly increased, co-ordination was affected but cerebellar functions were normal, abdominal reflex was absent with upgoing plantar on left side. All modalities of sensation were diminished without any trophic changes with normal bladder and bowel functions. Signs of autonomic disturbance were not detected. Neurological examination on the right side was normal and no external abnormality was noticed in head, neck and spine.

Blood examination was normal but urine examination showed: 2+ albumin, plenty of pus cells/HPF and growth of E. coli. CSF examination and radiological examination of chest were normal. In view of long history of seizure and as the previous CT scan was not available, we found it proper to order MRI of brain that showed marked right-sided hemicerebral atrophy with prominent involvement of cortex and sub-cortical white matter along with ipsilateral thickening of calvarium bones and dilation of para sinuses.

The UTI was treated and seizure was managed with slight modification in combination of anticonvulsant drugs. The patient was discharged and he is in regular followup visits.

\section{DISCUSSION}

Dyke-Davidoff and Masson described plain skull radiograph of nine patients presenting clinically with hemiparesis, seizure, mental retardation and facial asymmetry 1933.(1) 
Radiographic changes were ipsilateral dilation of frontal and ethmoid sinuses, thickening of calvarium and elevation of greater wing of sphenoid and petrous ridge. Alpers and Dear identified two types of cerebral hemiatrophy in 1939.(2) In congenital (primary) variety, whole hemisphere was characteristically hypoplastic. The secondary variety may be due to vascular lesion, inflammatory process or cranial trauma. The brain reaches half of its size during first year of life and 3/4th by the end of third year. The brain exert outward pressure on the bony table in case of normal development resulting in normal adult head shape, but in defective development bony structure tend to grow inwards resulting in various changes. These changes will be seen only when cerebral insult occurs before 3 years of age and these bony changes take 9 months to develop from the time of brain insult. Rasmussen encephalitis presents with similar cerebral hemiatrophy, but bony changes are usually lacking. Also, focal signs like loss of vision or aphasia commonly found in Rasmussen's encephalitis were absent in this case. Other differential diagnosis like Sturge-Weber Syndrome, some brain tumours, silver syndrome and linear nevus syndrome appeared remote on clinical and radiological grounds.

According to Zinkha $\mathrm{A}^{(3)}$ who defined the triad of hemiplegia, seizure and mental retardation, the seizure may appear months or years after the onset of hemiparesis and the mental retardation may not be always present. In our case, the dragging of the left foot was noticed at the age of 15 months and the first episode of seizure was experienced at the age of $10 \mathrm{yrs}$. As the patient is a teacher, his IQ should fall in range of normality (85 - 115). Hence, mental retardation was absent in this case. Thus, it is a rare presentation of a very rare disease.

\section{ACKNOWLEDGEMENTS}

This work was supported by PMCH-Patna, a college cum hospital funded by Bihar Government, India. Dr. Ram Dayal Singh and Dr. Kumar Abhinav acknowledge PMCH-Patna for Medical facilities.

\section{CONCLUSION}

Dyke-Davidoff Masson syndrome usually present with triad of hemiplegia seizure and mental retardation. But here in our case, the patient present without mental retardation. MRI also showed marked right-sided hemicerebral atrophy with prominent involvement of subcortical white matter along with ipsilateral thickening of calvarium bone and dilatation of parasinuses.

\section{REFERENCES}

[1] Dyke CG, Davidoff LM, Masson CB. Cerebral hemiatrophy \& homolateral hypertrophy of the skull \& sinuses. Surg Gynecol Obstet 1933;57:588-600.

[2] Alpers BJ, Dear RB. Hemiatrophy of the brain. J Nerve Ment Dis 1939;89:651-3.

[3] Zinkha A. CT of cerebral hemiatrophy. AJNR 1980;1(3):255-8. 